\title{
PENGARUH KOMPENSASI, KEPUASAN KERJA DAN PENGEMBANGAN KARIR TERHADAP RETENSI KARYAWAN DI KUTABEX HOTEL
}

\author{
Kadek Arya Reta Aditeresna ${ }^{1}$ \\ Ni Wayan Mujiati \\ ${ }^{1,2}$ Fakultas Ekonomi dan Bisnis Universitas Udayana (Unud), Bali, Indonesia \\ e-mail : retaarya@gmail.com
}

\begin{abstract}
ABSTRAK
Penelitian ini bertujuan untuk menjelaskan pengaruh kompensasi, kepuasan kerja dan pengembangan karir terhadap retensi karyawan. Penelitian ini dilakukan di Kutabex Hotel yang melibatkan 68 karyawan melalui metode sampel jenuh dan pengumpulan data dilakukan dengan observasi, wawancara dan kuesioner. Teknik analisis data yang digunakan adalah regresi linier berganda. Hasil penelitian ini menemukan bahwa kompensasi, kepuasan kerja dan pengembangan karir berpengaruh positif dan signifikan terhadap retensi karyawan. Pihak hotel hendaknya dapat memberikan kompensasi yang adil kepada karyawan untuk dapat meningkatkan retensi pada karyawan. Kepuasan kerja penting untuk diperhatikan karena ketika karyawan merasa puas dengan pekerjaannya maka akan meningkatkan tingkat retensinya. Dapat memperhatikan karir para karyawannya juga memiliki peran penting untuk dapat meningkatkan retensi.
\end{abstract}

Kata kunci: kompensasi, kepuasan kerja, pengembangan karir, retensi karyawan.

\begin{abstract}
The purpose of this study is to explain the effect of compensation, job satisfaction and career development on employee retention. This research was conducted in Kutabex Hotel involving 68 employees through saturated sample method and data collection was done by observation, interview and questionnaires. Data analysis technique used is multiple linier regression. The results of this study found that the compensation, job satisfaction and career development have a positive and significant impact on employee retention. The hotel should be able to provide fair compensation to employees to increase employee retention. Job satisfaction is important to note because when employees feel satisfied with their work it will increase the retention rate. Can pay attention to the careers of its employees also have an important role to be able to increase retention.
\end{abstract}

Keywords:compensation, job satisfaction, career development, employee retention. 


\section{PENDAHULUAN}

Perkembangan perusahaan pada era globalisasi ini mengalami persaingan yang sangat ketat. Perusahaan harus mampu melakukan pemberdayaan karyawannya untuk memenuhi kesuksesan perusahaan. Sumber daya manusia merupakan faktor penting dalam kesuksesan suatu perusahaan dengan dapat menjalankan fungsi serta tujuannya untuk pencapaian yang diinginkan oleh perusahaan. Sumber daya manusia juga merupakan aset yang berharga dalam perusahaaan sebagai penggagas keseluruhan dalam perusahaan. Tenaga kerja atau sumber daya manusia dapat mempengaruhi perkembangan hotel dan ikut berperan dalam menjalankan aktivitas hotel (Mustika, 2012).

Kegagalan mengelola sumber daya manusia dapat mengakibatkan timbulnya gangguan dalam pencapaian tujuan dalam organisasi, baik dalam kinerja, keuntungan, maupun kelangsungan hidup organisasi tersebut (Rayadi, 2012). Permasalahan yang timbul ketika salah mengelola sumber daya manusia yaitu penurunan kinerja karyawan. Keberhasilan perusahaan tergantung pada bagaimana kinerja karyawan, efisiensi, kejujuran, ketekunan, dan integritas (Ahmed dan Uddin, 2012).

Kinerja karyawan memiliki peranan penting bagi perusahaan, apabila kinerja yang ditampilkan karyawan rendah maka akan mengakibatkan perusahaan dalam mencapai tujuan menjadi terhambat (Ariana dan Riana, 2013). Dengan kehilangannya karyawan akan memperburuk keadaan maka dari itu perlunya ada retensi karyawan. Berdasarkan observasi, Kutabex Hotel menghadapi permasalahan dibidang retensi karyawan. Selama setahun terakhir, Kutabex Hotel 
hanya mampu mempertahankan 89,8 persen karyawan untuk tetap bekerja dihotel tersebut dan tingkat turnover yang dimiliki adalah sebesar 10,2 persen dan tergolong tinggi. Gillies (1989) menyatakan bahwa perputaran karyawan dikatakan normal berkisar antara 5-10 persen pertahun dan dikatakan tinggi apabila lebih dari 10 persen pertahun. Tabel 1 menguraikan tingginya tingkat turnover pada Kutabex Hotel pada tahun 2017.

Tabel 1.

Tingkat Turnover Kutabex Hotel Tahun 2017

\begin{tabular}{ccccc}
\hline Bulan & $\begin{array}{c}\text { Jumlah karyawan } \\
\text { (orang) }\end{array}$ & $\begin{array}{c}\text { Jumlah karyawan } \\
\text { tetap yang keluar } \\
\text { (orang) }\end{array}$ & $\begin{array}{c}\text { Turnover } \\
(\%)\end{array}$ & $\begin{array}{c}\text { Retensi } \\
(\%)\end{array}$ \\
\hline Januari & 75 & - & - & 100 \\
Februari & 75 & - & - & 100 \\
Maret & 74 & 1 & 1 & 99 \\
April & 74 & - & - & 100 \\
Mei & 74 & - & - & 100 \\
Juni & 73 & 1 & 1 & 99 \\
Juli & 73 & - & - & 100 \\
Agustus & 71 & 2 & 2 & 98 \\
September & 70 & 1 & 1 & 99 \\
Oktober & 70 & - & - & 100 \\
November & 68 & 2 & 2 & 98 \\
Desember & 68 & - & - & 100 \\
\hline Jumlah & $\mathbf{6 8}$ & $\mathbf{7}$ & $\mathbf{1 0 , 2}$ & $\mathbf{8 9 , 8}$
\end{tabular}

Sumber: HRD Kutabex Kuta Bali, 2018

Jennifer (2005:2) menyatakan retensi karyawan adalah teknik yang digunakan manajemen untuk mempertahankan karyawan agar tetap dalam perusahaan selama jangka waktu tertentu. Jika karyawan tidak dapat menggunakan potensinya dengan penuh dan tidak didengar atau dihargai ditempat mereka bekerja, mereka akan pergi karena stres dan frustasi (Oladapo, 2014). Bagi perusahaan mempertahankan orang - orang yang berkompeten sangat penting karena mempertahankan karyawan lebih baik daripada mencari karyawan baru (Ahlrichs, 
2000). Dengan rendahnya turnover karyawan maka perusahaan akan menghemat biaya - biaya salah satunya adalah biaya seleksi dan rekrutmen.

Fatima (2011) menyatakan tingginya retensi karyawan akan mempengaruhi kinerja organisasi dalam mencapai tujuan dan misi organisasi. Sumarni (2011) menyatakan bahwa tingginya employee retention sangat dibutuhkan dalam hal meningkatkan kinerja karyawan. Ketika tingkat turnover yang sangat tinggi menyebabkan terjadinya rendahnya tingkat retensi pada hotel kutabex. Menjaga tingginya retensi karyawan akan dapat meningkatkan efektifitas dan kinerja karyawan. Fitz-enz (1990) meyatakan bahwa retensi karyawan tidak dipengaruhi oleh faktor tunggal, tetapi ada faktor yang bertanggung jawab untuk mempertahankan karyawan dalam suatu organisasi.

Faktor untuk mempengaruhi tingkat retensi karyawan adalah kompensasi. Hasibuan (2011:118) menyatakan bahwa kompensasi adalah pendapatan berbentuk uang, barang langsung, atau tidak langsung yang diterima karyawan sebagai imbalan jasa yang diberikan. Lubis (2015) menyatakan bahwa kompensasi merupakan hal yang sangat penting bagi karyawan sebagai individu, karena upah merupakan suatu ukuran nilai atau karya mereka diantara para karyawan itu sendiri, keluarga, dan masyarakat. Dengan adanya kompensasi yang adil dapat memacu partisipasi karyawan sehingga para karyawan dapat bekerja dengan penuh tanggung jawab dan memiliki partisipasi kerja terhadap perusahaan (Philip et al., 2010). Astuti (2014) menyatakan melalui kompensasi karyawan akan lebih semangat untuk bekerja. Kompensasi memiliki hubungan yang erat dengan retensi karena jika 
kompensasi yang didapatkan karyawan itu dapat memenuhi kebutuhannya maka tingkat retensi karyawan tersebut juga tinggi.

Osteraker (1999) menyatakan kepuasan karyawan dan retensi merupakan faktor kunci untuk keberhasilan suatu organisasi. Kepuasan dapat menggambarkan perasaan positif dan negatif karyawan terhadap pekerjaan yang dihadapinya, seperti perasaan untuk meraih kesuksesan di dalam pekerjaan, mengimplementasikan kepuasan yang tinggi terhadap pegawai yang merasa senang dan nyaman dengan kondisi lingkungan organisasi dan mendapatkan penghargaan dari jeri payahnya (Aziri, 2011). Handoko (2014:193) menyatakan kepuasan kerja adalah keadaan emosional yang menyenangkan atau tidak menyenangkan para karyawan memandang pekerjaan mereka. Ketika karyawan memiliki perasaan yang positif mengenai perkerjaannya maka timbul rasa untuk tetap tinggal lebih lama di dalam perusahaan. Faktor kepuasan kerja juga menjadi sorotan penting yang harus dipenuhi. Seorang karyawan pasti ingin memiliki kepuasan dalam pekerjannya akan tetapi terkadang kepuasannya tidak dapat terpenuhi. Ketika karyawan merasakan kepuasan dalam bekerja maka karyawan tersebut akan bekerja dengan semaksimal mungkin. Individu yang merasa puas dengan pekerjaannya akan memiliki komitmen yang tinggi terhadap perusahaan dan keinginan untuk meninggakan perusahaan akan semakin rendah Iqbal et al. (2014).

Swaminathan (2013) menyatakan bahwa peningkatan kepuasan kerja akan mempengaruhi kualitas kerja karyawan, dimana akan memiliki pengaruh yang baik terhadap pencapain tujuan perusahan. Rizwan (2014) menyatakan bahwa meningkatkan kepuasan karyawan adalah kunci suksesnya organisasi bisnis, hal 
tersebut merupakan dasar bagi perusahaan untuk melihat seperti apa keinginan karyawan, lingkungan kerja yang diinginkan dan dengan hal tersebut akan dapat meningkatkan pengabdian karyawan.

Pengembangan karir merupakan aspek penting yang tidak boleh dilupakan dalam mengelola sumber daya manusia (Sari dan Sinulingga, 2011). Selain kompensasi dan kepuasan kerja, melalui adanya pengembangan karir akan dapat meningkatkan tingkat retensi karyawan. Pengembangan karir dapat dilakukan jika perusahaan dapat secara terbuka untuk memberikan kesempatan kepada karyawan untuk mengembangkan karirnya. Rivai (2011:274-279) menyatakan hal yang berkaitan dengan pengembangan karir seorang karyawan atau pegawai yaitu prestasi kerja (job performance), pengenalan (exposure), jaringan kerja (net working), pengunduran diri (resignations), kesetiaan terhadap organisasi (organizational loyality), pembimbing dan sponsor (mentors and sponsors), bawahan yang mempunyai peranan kunci (key subordinates), peluang untuk tumbuh (growth opportunies), pengalaman (experience). Pengembangan karir berdampak pada kinerja karyawan, dikarenakan pengembangan karir suatu pendekatan formal yang dilakukan perusahaan dengan tujuan menjamin karyawan di perusahaan dengan kualifikasi serta kemampuan dan pengalaman dengan tepat saat diperlukan (Kaseger, 2013).

Hasil wawancara sementara terhadap 5 orang karyawan yang bekerja pada Kutabex Hotel mereka menyatakan bahwa terdapat niat karyawan untuk bertahan di dalam perusahaan sangat tinggi. Faktor - faktor seperti kompensasi, kepuasan kerja, dan pengembangan karir memainkan peran penting dalam mendorong 
karyawan untuk tetap berada di Kutabex Hotel. Hal ini dapat dilihat dari beberapa keluhan yang muncul dari karyawan, seperti misalnya: jarangnya insentif yang diterima karyawann saat mereka melakukan pekerjaan tambahan, tekanan dari atasan dalam pencapaian target penjualan kamar hotel, hubungan antara atasan dan bawahan terkadang sering terjadi kecanggungan, serta dukungan untuk menapaki jenjang karir dalam organisasi. Adanya masalah yang timbul maka peneliti tertarik untuk melakukan penelitian mengenai Pengaruh Kompensasi, Kepuasan kerja, dan Pengembangan Karir Terhadap Retensi Karyawan di Kutabex Hotel.

Rumusan masalah dalam penelitian ini (1) Bagaimanakah pengaruh kompensasi terhadap retensi karyawan? (2) Bagaimanakah pengaruh kepuasan kerja terhadap retensi karyawan? (3) Bagaimanakah pengaruh pengembangan karir terhadap retensi karyawan?. Tujuan penelitian ini (1) untuk menganalisi pengaruh kompensasi terhadap retensi karyawan; (2) untuk menganalisis pengaruh kepuasan kerja terhadap retensi karyawan; (3) untuk menganalisis pengaruh pengembangan karir terhadap retensi karyawan.

Kegunaan penelitian ini dapat memberikan manfaat secara teoritis adalah memberikan wawasan yang lebih luas terhadap perusahaan akan pengaruh kompensasi, kepuasan kerja dan pengembangan karir terhadap retensi karyawan. kegunaan praktis penelitian ini adalah sebagai pertimbangan manajer perusahaan dalam dalam membuat kebijakan sumber daya manusia terutama yang berkaitan dengan kompensasi, kepuasan kerja, pengembangan karir guna meningkatkan retensi karyawan di Kutabex Hotel. 
Ragupathi (2013) menyatakan retensi karyawan merupakan teknik yang digunakan oleh manajemen untuk membantu karyawan agar tetap dengan organisasi untuk jangka waktu yang lama. Karthi (2012) menyatakan bahwa retensi karyawan adalah proses bagaimana cara mendorong karyawan untuk tetap dengan organisasi untuk periode maksimum waktu atau sampai selesainya proyek. Retensi karyawan merupakan kemampuan perusahaan untuk mempertahankan karyawan yang memiliki potensi untuk tetap loyal terhadap perusahaan (Susilo, 2013). Retensi karyawan juga merupakan keingian karyawan untuk bertahan di dalam suatu perusahaan dalam jangka waktu yang lama. Karyawan harus diperhatikan secara menyeluruh oleh manajer untuk menghindari hal seperti, menurunnya semangat kerja, loyalitas, sikap dan disiplin karyawan.

Tujuan dari retensi karyawan yakni untuk mempertahankan karyawan yang dianggap memiliki kualitas selama mungkin, karena karyawan yang memiliki kualitas terbaik merupakan suatu faktor pendukung dalam memajukan organisasi. Berdasarkan pengertian diatas, bahwa retensi karyawan adalah suatu proses yang dilakukan perusahaan untuk dapat mempertahankan karyawan yang potensial agar tetap loyal terhadap perusahaan dengan jangka waktu yang lebih lama.

Handaru (2013) menyatakan kompensasi merupakan bentuk penghargaan yang diberikan kepada karyawan sebagai balas jasa atau kontribusi yang mereka berikan kepada organisasinya. Besarnya kompensasi atau balas jasa telah ditentukan dan diketahui sebelumnya, sehingga karyawan secara pasti akan mengetahui besar balas jasa atau kompensasi yang akan diterima oleh karyawan tersebut (Anas, 2011). Besarnya kompensasi mencerminkan status, pengakuan, dan 
tingkat pemenuhan kebutuhan yang dinikmati oleh karyawan beserta keluarganya. Vicky (2012) menyatakan bahwa kompensasi adalah strategi perusahaan untuk memberdayakan tenaga kerja, dan dapat berfungsi sebagai keunggulan kompetitif perusahaan. Kompensasi merupakan alasan yang utama bagi karyawan untuk bergabung dalam sebuah perusahaan. Kompensasi yang adil lebih mungkin untuk menarik dalam mengembangkan, memotivasi dan mempertahankan pegawai yang bekualitas dan berkompeten (Arya Wibawa, 2015).

Puangyoykeaw dan Nishide (2015) menyatakan kepuasan kerja merupakan tingkat kepuasan yang dirasakan karyawan terkait dengan pekerjaan karyawan. Handoko (2014:193) menyatakan kepuasan kerja adalah keadaan emosional yang menyenangkan atau tidak menyenangkan para karyawan memandang pekerjaan mereka. Kepuasaan kerja mencerminkan perasaan seseorang terhadap pekerjaannya. Kepuasan kerja dapat ditinjau dari dua sisi, yaitu dari sisi karyawan dan sisi perusahaan. Kepuasan kerja dari sisi karyawan akan memunculkan perasaan senang dalam bekerja, sedangkan dari sisi perusahaan, kepuasan kerja akan meningkatkan produktivitas, perbaikan sikap, dan tingkah laku karyawan dalam memberikan pelayanan prima (Suwanto dan Priansa, 2011).

Pendapat para ahli diatas menyatakan bahwa kepuasan kerja merupakan penilaian dari pekerja tentang seberapa jauh pekerjaannya secara keseluruhan memuaskan kebutuhannya. Kepuasan kerja akan menyebabkan kondisi kerja yang baik, dengan kondisi kerja yang baik akan mendorong karyawan memaksimalkan segala kemampuannya untuk menyelesaikan pekerjaan sehingga dapat mencapai tujuan individu ataupun organisasi. 
Pengembangan karir adalah proses peningkatan kemampuan kerja individu yang dicapai dalam rangka mencapai karir yang diinginkan (Sudiro, 2011:91). Definisi lain pengembangan karir adalah proses pengidentifikasi kemampuan karir karyawan dan melalui penerapan model yang tepat untuk mendapatkannya (Haryani, 2013). Pendapat dari beberapa para ahli diatas menyatakan bahwa pengembangan karir adalah suatu proses rangkaian kegiatan untuk meningkatkan kompetensi serta kemampuan kerja individu karyawan untuk merencanakan karir dimasa sekarang dan masa depan selama masa kerjanya sehingga mampu mencapai jenjang jabatan atau pangkat.

Kumar et al. (2012) menemukan bahwa karyawan akan merasa dihargai oleh perusahaan jika mereka mendapatkan kompensasi yang layak. Secara tidak langsung karyawan akan termotivasi serta memiliki niat untuk tinggal di perusahaan. Sistem upah yang efisien mempengaruhi karyawan untuk tingal lebih lama, karena jika kompensasinya yang didapatkan sesuai dengan pekerjaanya maka karyawan tersebut akan tinggal lebih lama Moncarz et al. (2009). Penelitian yang dilakukan oleh Swambawa Putra (2016) menjelaskan apabila kompensasi yang tinggi maka retensi karyawan meningkat. Masqsood et al. (2015) menemukan bahwa kompensasi berkontribusi untuk meningkatkan retensi karyawan. Palwasha et al. (2016) menemukan bahwa kompensasi sebagai faktor penting yang mempengaruhi niat karyawan untuk tinggal. Hipotesis yang dapat diajukan dalam penelitian ini, berdasarkan hasil penelitian sebelumnya adalah sebagai berikut.

$\mathrm{H}_{1}$ : Kompensasi berpengaruh positif dan signifikan terhadap retensi karyawan. 
Kepuasan kerja berpengaruh terhadap keputusan karyawan untuk tinggal atau meninggalkan organisasi, jika mereka karyawan percaya bahwa mereka diperlukan secara adil dan mendapatkan penghargaan, mereka tidak akan mungkin untuk meninggalkan organisasi sebaliknya jika karyawan merasa tidak puas dengan pekerjaan mereka, mereka cenderung meninggalkan organisasninya Aydogdu dan Asikgil (2011). Penelitian yang dilakukan oleh Das dan Baruah (2013) mengatakan bahwa berpengaruh siginifikan hubungan antara kepuasan kerja terhadap retensi karyawan, karena semakin tingginya tingkat kepuasan kerja maka akan lebih rendahnya niat untuk keluarnya karyawan.

Witasari (2009) juga menambahkan bahwa kepuasan keja memiliki hubungan yang negatif dengan turnover intention, yang mengartikan bahwa kepuasan kerja berpengaruh positif terhadap retensi karyawan. Pada penelitian Astuti (2014) menyimpulkan bahwa semaki besar kepuasan kerja maka akan semakin tinggi retensi karyawan, dapat dikatakan karyawan yang puas memiliki niat yang lebih tinggi untuk bertahan dengan perusahaan. Oleh karena itu kepuasan kerja faktor terpenting yang harus diperhatikan. Motlou et al. (2016) menemukan bahwa kepuasan kerja berpengaruh terhadap retensi karyawan, karena ketika karyawan merasa puas terhadap pekerjaannya maka meningkatkan tingkat retensi. Hipotesis yang dapat diajukan dalam penelitian ini, berdasarkan hasil penelitian sebelumnya adalah sebagai berikut.

$\mathrm{H}_{2}$ : Kepuasan Kerja berpengaruh positif dan signifikan terhadap retensi karyawan.

Penelitian yang dilakukan oleh Kwenin (2013) menemukan bahwa pengembangan karir secara signifikan mempengaruhi retensi karyawan di 
Vodafone Ghana Limited. Ongori dan Agolla (2009) menyatakan bahwa pengembangan karir berperan penting dalam organisasi akan menyebabkan peningkatan niat karyawan untuk meninggalkan organisasi. Prince (2005) menyarankan bahwa organisasi harus mendukung karyawan untuk membuat komitmen jangka panjang kepada karyawan melalui peningkatan program pelatihan dan pengembangan karir.

Penelitian yang dilakukan oleh Mehta dan Kurbetti (2014) Menyediakan peluang pengembangan karir yang hebat membuat karyawan tetap tinggal lama di perusahaan dan secara tidak langsung akan meningkatkan tingkat loyalitas kepada perusahaan. Khan (2014) menemukan bahwa pengembangan karir meningkatkan retensi karyawan terhadap perusahaan. Hipotesis yang dapat diajukan dalam penelitian ini, berdasarkan hasil penelitian sebelumnya adalah sebagai berikut.

$\mathrm{H}_{3}$ : Pengembangan karir berpengaruh positif dan signifikan terhadap retensi karyawan.

Kerangka konseptual berdasarkan hipotesis yang diusulkan pada Gambar 1.

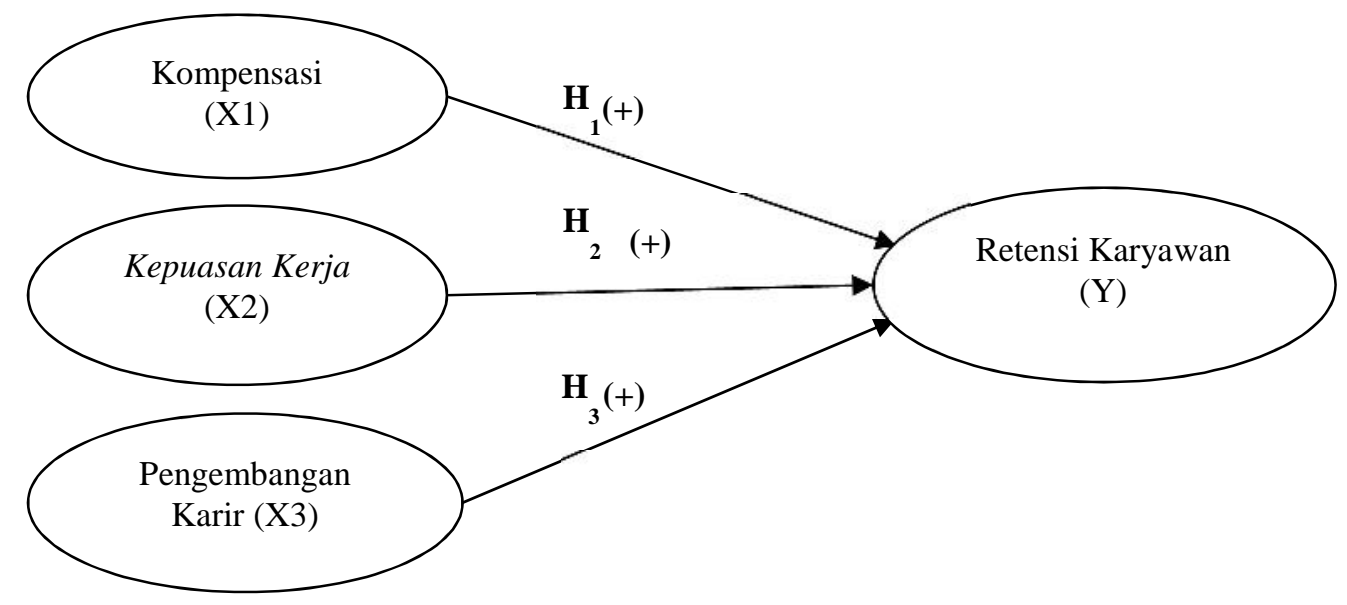

\section{Gambar 1. Kerangka Konsep}




\section{METODE PENELITIAN}

Desain penelitian ini menggunakan pendekatan kuantitatif yang bersifat asosiatif. Lokasi penelitian ini adalah Kutabex Hotel yang beralamat di Jalan Raya Kuta, Badung, Bali. Objek dalam penelitian ini adalah (1) Kompensasi, (2) Kepuasan kerja, (3) Pengembangan karir, dan (4) Retensi Karyawan Kutabex Hotel.

Tabel 2.

Indikator-indikator Variabel

\begin{tabular}{|c|c|c|c|}
\hline No & Variabel & Indikator & Sumber \\
\hline \multirow[t]{3}{*}{1} & Retensi & $\mathrm{Y}_{1}$ Tersedianya peluang karir & \\
\hline & Karyawan & $\mathrm{Y}_{2}$ Rekan kerja tidak diskriminatif & Hong (2012) \\
\hline & & $\mathrm{Y}_{3}$ Pengahargaan yang diberikan & \\
\hline \multirow[t]{5}{*}{2} & Kompensasi & $\mathrm{X}_{1.1}$ Gaji & \\
\hline & & $\mathrm{X}_{1.2}$ Bonus & Simamora (2004: 445) \\
\hline & & $\mathrm{X}_{1.3}$ Tunjangan hari raya & \\
\hline & & $\mathrm{X}_{1.4}$ Fasilitas kesehatan & \\
\hline & & $\mathrm{X}_{1.5}$ Fasilitas bekerja & \\
\hline \multirow[t]{5}{*}{3} & Kepuasan & $\mathrm{X}_{2.1}$ Pekerjaan menarik & \\
\hline & Kerja & $\mathrm{X}_{2.2}$ Merasa puas dengan gaji & \\
\hline & & $\mathrm{X}_{2.3}$ Merasa puas dengan dukungan atasan & Azeem (2010) \\
\hline & & $\mathrm{X}_{2.4}$ Kesempatan memperoleh promosi & \\
\hline & & $\mathrm{X}_{2.5}$ Rasa senang dengan rekan kerja & \\
\hline \multirow[t]{5}{*}{4} & Pengembangan & $\mathrm{X}_{3.1}$ Perlakuan yang adil & \\
\hline & Karir & $\mathrm{X}_{3.2}$ Atasan mendukung pengembangan karir & A.Sitohang (2007: 213) \\
\hline & & $\mathrm{X}_{3.3}$ Berkompeten dibidang pekerjaan & \\
\hline & & $\mathrm{X}_{3.4}$ Minat dipromosikan atasan & \\
\hline & & $\mathrm{X}_{3.5}$ Memiliki latarbelakang pendidikan & \\
\hline
\end{tabular}

Populasi dari penelitian ini adalah seluruh karyawan Kutabex Hotel. Metode yang digunakan dalam penentuan sampel adalah metode sampling jenuh, menyatakan semua anggota populasi digunakan sebagai sampel penelitian. Sampel dalam penelitian ini adalah seluruh karyawan Kutabex Hotel yang berjumlah 68 orang. 
Jenis data yang digunakan dalam penelitian ini ada 2 yaitu data kualitatif mengartikan gambaran umum obyek penelitian. Data Kuantitatif yaitu jumlah pegawai tetap, jumlah sarana dan prasarana, dan hasil angket. Sumber data yang digunakan yaitu sumber primer data yang diperoleh dari wawancara dengan beberapa karyawan Kutabex Hotel. Sedangkan sumber sekunder diperoleh dari perusahaan yang dapat dilihat dokumentasi perusahaan, buku-buku referensi, dan informasi lain yang berhubungan dengan penelitian.

Data dikumpulkan menggunakan instrumen penelitian berupa kuesioner. Kuesioner terdiri dari pernyataan terbuka dan pernyataan tertutup. Pernyataan tertutup mengenai identitas responden seperti nama, usia, jenis kelamin, pendidikan terakhir, dan lama bekerja. Pernyataan terbuka terdiri mengenai sejumlah pernyataan yang meminta pendapat responden tentang penilaian terhadap sejumlah indikator dari setiap variabel yang berupa indikator variabel kompensasi, kepuasan kerja, pengembangan karir dan retensi karyawan. Tiap indikator variabel penelitian diberi pilihan jawaban dengan menggunakan skala Likert.

Sebelum digunakan, instrumen penelitian terlebih dahulu diuji untuk mengetahui validitas dan reliabilitasnya. Pernyataan-pernyataan dalam kuesioner dikatakan valid apabila koefisien korelasi $\geq 0,3$ (Sugiyono, 2016:142). Uji validitas instrumen bertujuan untuk memeriksa apakah kuesioner sebagai instrumen penelitian sudah tepat dalam mengukur indikator penelitian. Uji reliabilitas dilakukan untuk mengetahui konsistensi alat ukur yang digunakan, sehingga bila alat ukur tersebut digunakan kembali maka akan memperoleh hasil yang sama. Uji 
reliabilitas data dengan menggunakan formula Alpha Cronbach $\geq 0,6$ (Sugiyono, 2016:147).

Metode regresi linier beranda digunakan dalam penelitian ini untuk mengetahui pengaruh Kompensasi $\left(\mathrm{X}_{1}\right)$, Kepuasan Kerja $\left(\mathrm{X}_{2}\right)$, Pengembangan Karir $\left(\mathrm{X}_{3)}\right.$ dan Retensi Karyawan $(\mathrm{Y})$. metode ini diuji menggunakan sistem komputer berupa spss.2.3. Pengaruh variabel independen terhadap variabel dependen diuji dengan tingkat kepercayaan 95\% atau $\alpha=5 \%$. Model regresi yang digunakan adalah sebagai berikut.

$\mathrm{Y}=\alpha+\beta 1 \mathrm{X} 1+\beta 2 \mathrm{X} 2+\beta 3 \mathrm{X} 3 \mathrm{e}$

Keterangan:

$\mathrm{Y}=$ Retensi Karyawan

$\mathrm{X} 1$ = Kompensasi

$\mathrm{X} 2$ = Kepuasan Kerja

$\mathrm{X} 3$ = Pengembangan Karir

$\alpha=$ Konstanta

$\beta 1=$ Koefisien regresi Kompensasi

$\beta 2=$ Koefisien regresi Kepuasan Kerja

$\beta 3=$ Koefisien regresi Pengembangan Karir

$\mathrm{e}=$ eror

Sebelum digunakannya teknik analisis regresi linier berganda maka dilakukan uji asumsi klasik. Uji asumsi klasik berfungai untuk menilai persyaratan persyaratan yang harus dipenuhi didalam teknik regresi linier berganda agar mendapatkan hasil yang valid. Jenis asumsi klasik yang digunakan dalam penelitian ini adalah uji normalitas, uji heteroskedastisitas dan uji multikolinieritas.

Uji F memiliki tujuan untuk menunjukkan kelayakan model regresi linier berganda sebagai alat analisis yang menguji pengaruh variabel bebas terhadap variabel terikat. Koefisien determinasi ( $R$ Square) pada intinya mengukur seberapa 
jauh kemampuan model dalam menerangkan variasi variabel terikat. Uji $\mathrm{t}$ dipergunakan untuk menguji pengaruh dari variabel kompensasi, kepuasan kerja, dan pengembangan karir terhadap variabel retensi karyawan terikatnya secara parsial.

\section{HASIL DAN PEMBAHASAN}

Responden yang digunakan pada penelitian ini berjumlah 68 responden yang meliputi empat aspek karakteristik, yaitu: jenis kelamin, usia, pendidikan terakhir dan masa kerja. Karakteristik responden dapat dilihat pada Tabel 3.

Tabel 3.

Karakteristik Responden

\begin{tabular}{|c|c|c|c|c|}
\hline No & Variabel & Klasifikasi & $\begin{array}{l}\text { Jumlah } \\
\text { (Orang) }\end{array}$ & $\begin{array}{c}\text { Presentase } \\
(\%)\end{array}$ \\
\hline \multirow{4}{*}{1} & & 20 - 30 Tahun & 44 & 64,71 \\
\hline & Usia & 31 - 40 Tahun & 19 & 27,94 \\
\hline & & 41 - 50 Tahun & 5 & 7,35 \\
\hline & & Jumlah & 68 & 100,0 \\
\hline \multirow[t]{4}{*}{2} & Jenis & Laki-laki & 42 & 61,76 \\
\hline & Kelamin & Perempuan & 26 & 38,24 \\
\hline & & Jumlah & 68 & 100,0 \\
\hline & & SMA & 30 & 44,12 \\
\hline \multirow[t]{6}{*}{3} & Pendidikan & D1 & 12 & 17,65 \\
\hline & Terakhir & D2 & 6 & 8,82 \\
\hline & & D3 & 8 & 11,76 \\
\hline & & S1 & 12 & 17,65 \\
\hline & & Jumlah & 68 & 100,0 \\
\hline & & $1-5$ tahun & 32 & 47,06 \\
\hline \multirow[t]{3}{*}{4} & Masa Kerja & $6-10$ tahun & 26 & 38,23 \\
\hline & & $11-15$ tahun & 10 & 14,71 \\
\hline & & Jumlah & 68 & 100,0 \\
\hline
\end{tabular}

Sumber : Data primer diolah, 2018

Tabel 3 menunjukkan sebagian besar responden didominasi oleh responden yang berusia pada rentang 20-30 tahun sebesar 64,71\%. Pembagian berdasarkan jenis kelamin menunjukkan respoden didominsasi oleh laki-laki sebesar 61,76\%. Dilihat dari pendidikan terakhir, sebesar $44,12 \%$ responden berpendidikan SMA 
dan masa pekerja responden didominasi dengan masa kerja 1-5 tahun sebesar $47,06 \%$.

Tabel 4. Hasil Uji Validitas dan Reliabilitas

\begin{tabular}{cccc}
\hline Variabel & Instrumen & $\begin{array}{c}\text { Koefisien } \\
\text { Korelasi }\end{array}$ & $\begin{array}{c}\text { Koefisien } \\
\text { Reliabilitas }\end{array}$ \\
\hline \multirow{2}{*}{ Retensi Karyawan } & $\mathrm{Y}_{1}$ & 0,747 & 0,670 \\
$(\mathrm{Y})$ & $\mathrm{Y}_{2}$ & 0,707 & \\
& $\mathrm{Y}_{3}$ & 0,752 & \\
& $\mathrm{X}_{1.1}$ & 0,343 & \\
Kompensasi & $\mathrm{X}_{1.2}$ & 0,765 & 0,728 \\
(X1) & $\mathrm{X}_{1.3}$ & 0,486 & \\
& $\mathrm{X}_{1.4}$ & 0,755 & \\
& $\mathrm{X}_{1.5}$ & 0,696 & 0,615 \\
Kepuasan Kerja & $\mathrm{X}_{1.6}$ & 0,596 & \\
(X2) & $\mathrm{X}_{1.7}$ & 0,612 & \\
& $\mathrm{X}_{2.1}$ & 0,630 & 0,644 \\
& $\mathrm{X}_{2.2}$ & 0,692 & \\
& $\mathrm{X}_{2.3}$ & 0,594 & \\
Pengembangan Karir & $\mathrm{X}_{2.4}$ & 0,625 & \\
$(\mathrm{X} 3)$ & $\mathrm{X}_{2.5}$ & 0,387 & \\
& $\mathrm{X}_{3.1}$ & 0,697 & \\
& $\mathrm{X}_{3.2}$ & 0,607 & \\
& $\mathrm{X}_{3.3}$ & 0,530 & \\
& $\mathrm{X}_{3.4}$ & 0,647 & \\
& $\mathrm{X}_{3.5}$ & 0,647 & \\
& $\mathrm{X}_{3.6}$ & 0,480 & \\
\hline
\end{tabular}

Sumber : Data diolah, 2018

Hasil uji validitas dan Reliabilitas instrumen penelitian disajikan pada Tabel 4 yang menunjukkan bahwa seluruh indikator dalam variabel memiliki nilai koefisien validitas yang lebih besar dari angka 0,30 sehingga seluruh indikator tersebut dikatakan telah memenuhi syarat validitas data. Koefisien Reliabilitas menunjukkan bahwa seluruh variabel memiliki koefisien koefisien reliabilitias yang lebih besar dari angka 0,60 . Hal ini dapat dikatakan bahwa semua instrumen reliabel sehingga dapat digunakan untuk penelitian.

Deskripsi data variabel menggambarkan penilaian dari pernyataan yang terdapat dalam kuesioner penelitian terdiri dari pernyataan berdasarkan variabel retensi karyawan, kompensasi, kepuasan kerja serta pengembangan karir. 
Tabel 5.

Deskripsi Jawaban Responden terhadap Retensi Karyawan

\begin{tabular}{|c|c|c|c|c|c|c|c|c|}
\hline \multirow{2}{*}{ No } & \multirow{2}{*}{ Indikator } & \multicolumn{4}{|c|}{ Skor Jawaban } & \multicolumn{2}{|r|}{ Jumlah } & \multirow{2}{*}{$\begin{array}{l}\text { Rata - Rata } \\
\text { Skor } \\
\end{array}$} \\
\hline & & 1 & 2 & 3 & 4 & 5 & Skor & \\
\hline 1 & $\begin{array}{l}\text { Perusahaan menyediakan } \\
\text { peluang karir yang sama } \\
\text { bagi setiap karyawan. }\end{array}$ & 0 & 2 & 7 & 41 & 18 & 279 & 4,1 \\
\hline 2 & $\begin{array}{l}\text { Rekan kerja tidak } \\
\text { pernah bertindak diskriminatif. }\end{array}$ & 1 & 2 & 7 & 40 & 18 & 276 & 4,06 \\
\hline 3 & $\begin{array}{l}\text { Perusahaan selalu } \\
\text { memberikan penghargaan } \\
\text { atas kinerja yang dilakukan. }\end{array}$ & 0 & 2 & 16 & 29 & 21 & 273 & 4,01 \\
\hline
\end{tabular}

Sumber : Data diolah, 2018

Tabel 5 menunjukkan semua indikator memiliki nilai rata-rata diantara 3,41 s/d 4,20 yang berarti indikator-indikator tersebut sudah dinilai baik. Demikian juga dengan nilai rata-rata variabel retensi karyawan yang memiliki nilai sebesar 4,07 ini berarti variabel retensi karyawan masuk dalam kriteria baik. Artinya, karyawan akan tetap tinggal di Kutabex Hotel ketika perusahaan menyediakan peluang karir yang sama bagi setiap karyawan, rekan kerja tidak bertindak diskriminatif, dan perusahaan memberikan penghargaan atas kinerja yang dilakukan.

Tabel 6.

Deskripsi Jawaban Responden terhadap Kompensasi

\begin{tabular}{|c|c|c|c|c|c|c|c|c|}
\hline \multirow{2}{*}{ No } & \multirow{2}{*}{ Indikator } & \multicolumn{4}{|c|}{ Skor Jawaban } & \multicolumn{2}{|r|}{ Jumlah } & \multirow{2}{*}{$\begin{array}{l}\text { Rata - Rata } \\
\text { Skor }\end{array}$} \\
\hline & & 1 & 2 & 3 & 4 & 5 & Skor & \\
\hline \multirow[t]{2}{*}{1} & Mendapatkan gaji & & & & & & & \\
\hline & tepat waktu setiap bulan & 0 & 0 & 7 & 35 & 26 & 291 & 4,79 \\
\hline \multirow[t]{3}{*}{2} & Mendapatkan bonus & & & & & & & \\
\hline & jika memenuhi target & 0 & 6 & 11 & 29 & 22 & 271 & 3,99 \\
\hline & Perusahaan & & & & & & & \\
\hline 3 & $\begin{array}{l}\text { Mendapatkan tunjangan } \\
\text { hari raya setiap tahun }\end{array}$ & 1 & 3 & 7 & 30 & 27 & 283 & 4,16 \\
\hline 4 & $\begin{array}{l}\text { Mendapat tunjangan } \\
\text { bayaran cuti tahunan. }\end{array}$ & 1 & 8 & 7 & 31 & 21 & 267 & 3,93 \\
\hline 5 & $\begin{array}{l}\text { Mendapat tunjangan } \\
\text { berupa dana pensiun. }\end{array}$ & 0 & 4 & 13 & 32 & 19 & 270 & 3,97 \\
\hline 6 & Mendapat fasilitas & 0 & 0 & 10 & 27 & 31 & 293 & 4,31 \\
\hline & kesehatan dan keluarga. & & & & & & & \\
\hline 7 & $\begin{array}{l}\text { Mendapat fasilitas } \\
\text { untuk bekerja. }\end{array}$ & 0 & 1 & 12 & 28 & 27 & 285 & 4,19 \\
\hline
\end{tabular}


Tabel 6 menunjukkan semua indikator memiliki nilai rata-rata diantara 3,41 s/d 4,20 yang berarti indikator-indikator tersebut sudah dinilai baik. Demikian juga dengan nilai rata-rata variabel kompensasi yang memiliki nilai sebesar 3,51 ini berarti variabel kompensasi masuk dalam kriteria baik. Artinya, kompensasi yang diberikan oleh Kutabex Hotel baik ketika memberikan gaji tepat waktu, mendapatkan bonus, tunjangan hari raya, dana pensiun, dan fasilitas kesehatan.

Tabel 7.

Deskripsi Jawaban Responden terhadap Kepuasan Kerja

\begin{tabular}{|c|c|c|c|c|c|c|c|c|}
\hline \multirow{2}{*}{ No } & \multirow{2}{*}{ Indikator } & \multicolumn{5}{|c|}{ Skor Jawaban } & Jumlah & \multirow{2}{*}{$\begin{array}{l}\text { Rata - Rata } \\
\text { Skor }\end{array}$} \\
\hline & & 1 & 2 & 3 & 4 & 5 & Skor & \\
\hline 1 & $\begin{array}{l}\text { Pekerjaan yang di } \\
\text { kerjakan sangat menarik }\end{array}$ & 0 & 1 & 6 & 43 & 18 & 282 & 4,15 \\
\hline 2 & $\begin{array}{l}\text { Puas dengan gaji yang } \\
\text { di terima untuk tanggung } \\
\text { jawab pekerjaan saya }\end{array}$ & 0 & 3 & 8 & 39 & 18 & 276 & 4,06 \\
\hline 3 & $\begin{array}{l}\text { Puas dengan adanya } \\
\text { dukungan atasan }\end{array}$ & 0 & 1 & 6 & 29 & 32 & 296 & 4,35 \\
\hline 4 & $\begin{array}{l}\text { Adanya kesempatan untuk } \\
\text { memperoleh promosi }\end{array}$ & 0 & 0 & 16 & 24 & 28 & 284 & 4,18 \\
\hline 5 & $\begin{array}{l}\text { Senang dengan } \\
\text { hubungan yang baik } \\
\text { dengan rekan kerja }\end{array}$ & 0 & 0 & 5 & 27 & 35 & 303 & 4,46 \\
\hline
\end{tabular}

Total Rata - Rata Skor

Sumber : Data diolah, 2018

Tabel 7 menunjukkan semua indikator memiliki nilai rata-rata diantara 4,21 s/d 5,00 yang berarti indikator-indikator tersebut sudah dinilai sangat baik. Demikian juga dengan nilai rata-rata variabel kepuasan kerja yang memiliki nilai sebesar 4,24 ini berarti variabel kepuasan kerja masuk dalam kriteria sangat baik. Artinya, karyawan akan merasa puas terhadap Kutabex Hotel ketika pekerjaan yang dikerjakan sangat menarik, merasa puas dengan gaji yang dibayarkan, memperoleh kesempatan untuk dipromosikan, dan memiliki hubungan baik dengan rekan kerja. 
Tabel 8.

Deskripsi Jawaban Responden terhadap Pengembangan Karir

\begin{tabular}{|c|c|c|c|c|c|c|c|c|}
\hline \multirow{2}{*}{ No } & \multirow{2}{*}{ Indikator } & \multicolumn{5}{|c|}{ Skor Jawaban } & \multirow{2}{*}{$\begin{array}{l}\text { Jumlah } \\
\text { Skor }\end{array}$} & \multirow{2}{*}{$\begin{array}{l}\text { Rata - Rata } \\
\text { Skor }\end{array}$} \\
\hline & & 1 & 2 & 3 & 4 & 5 & & \\
\hline 1 & $\begin{array}{l}\text { Perusahaan memberikan } \\
\text { perlakuan yang adil pada } \\
\text { setiap karyawan dalam } \\
\text { pengembangan karir }\end{array}$ & 0 & 2 & 6 & 35 & 25 & 287 & 4,22 \\
\hline 2 & $\begin{array}{l}\text { Atasan selalu } \\
\text { mendukung pengembangan } \\
\text { karir karyawannya }\end{array}$ & 0 & 0 & 11 & 29 & 28 & 289 & 4,25 \\
\hline 3 & $\begin{array}{l}\text { Berkompeten dibidang } \\
\text { pekerjaan sekarang }\end{array}$ & 0 & 0 & 8 & 37 & 23 & 287 & 4,22 \\
\hline 4 & $\begin{array}{l}\text { Merasa cukup memiliki } \\
\text { informasi mengenai } \\
\text { promosi jabatan yang } \\
\text { ada di perusahaan }\end{array}$ & 0 & 1 & 11 & 35 & 21 & 280 & 4,12 \\
\hline 5 & Berminat untuk & 0 & 0 & 10 & 33 & 25 & 287 & 4,22 \\
\hline 6 & $\begin{array}{l}\text { Memiliki latar belakang } \\
\text { pendidikan formal yang } \\
\text { cukup untuk mampu bekerja } \\
\text { di perusahaan ini }\end{array}$ & 0 & 0 & 15 & 29 & 5 & 280 & 4,12 \\
\hline Tot & Rata - Rata Skor & & & & & & & 4,19 \\
\hline
\end{tabular}

Tabel 8 menunjukkan bahwa deskripsi jawaban responden terhadap pengembangan karir di Kutabex Hotel dalam kriteria baik. Secara rinci, dapat diketahui semua indikator memiliki nilai rata-rata diantara 3,41 s/d 4,20 yang berarti indikator-indikator tersebut sudah dinilai baik. Demikian juga dengan nilai rata-rata variabel kompensasi yang memiliki nilai sebesar 4,19 ini berarti variabel pengembangan karir masuk dalam kriteria baik. Artinya, pengembangan karir di Kutabex Hotel sangat baik ketika perusahaan dapat berlaku adil dalam pengembangan karir, atasan selalu mendukung pengembangan karir karyawannya, memiliki kompetensi dibidang pekerjaannya, berminat untuk dipromosikan, dan memiliki latar belakang pendidikan formal untuk mampu bekerja di perusahaan.

Analisis regresi linier berganda penelitian ini diperoleh hasil yang ditunjukkan pada Tabel 9. 
Tabel 9.

Hasil Uji Analisis Regresi Linier Berganda

\begin{tabular}{|c|c|c|c|c|c|}
\hline \multirow[t]{2}{*}{ Model } & \multicolumn{2}{|c|}{$\begin{array}{l}\text { Unstandardized } \\
\text { Coefficients }\end{array}$} & \multirow{2}{*}{$\begin{array}{l}\text { Standardized } \\
\text { Coefficients } \\
\text { Beta }\end{array}$} & \multirow[t]{2}{*}{$\mathbf{T}$} & \multirow[t]{2}{*}{ Sig. } \\
\hline & $\mathbf{B}$ & Std. Error & & & \\
\hline (Constant) & 0,427 & 1,766 & & 0,425 & 0,602 \\
\hline Kompensasi & 0,128 & 0,064 & 0,193 & 2,009 & 0,028 \\
\hline Kepuasan Kerja & 0,174 & 0,080 & 0,267 & 2,180 & 0,032 \\
\hline Pengembangan Karir & 0,298 & 0,120 & 0,297 & 2,473 & 0,016 \\
\hline R Square & & & & & 0,468 \\
\hline F Stastistik & & & & & 13,999 \\
\hline Signifikansi & & & & & 0,000 \\
\hline
\end{tabular}

Sumber : Data diolah, 2018

Hasil analisis regresi linier berganda seperti yang ditunjukkan pada Tabel 9, maka persamaan regresinya adalah sebagai berikut.

$$
\mathrm{Y}=0,427+0,128 \mathrm{X}_{1}+0,174 \mathrm{X}_{2}+0,298 \mathrm{X}_{3}+\mathrm{e}
$$

Interprestasi dari persamaan regresi diatas dapat dijelaskan bahwa kompensasi, kepuasan kerja, dan pengembangan karir berpengaruh positif terhadap retensi karyawan. Nilai $\beta_{1}$ menunjukkan bahwa ada pengaruh positif antara kompensasi dengan retensi karyawan sebesar 0,128 . Nilai $\beta_{2}$ menunjukan bahwa ada pengaruh positif antara kepuasan kerja dengan retensi karyawan sebesar 0,174. Nilai $\beta_{3}$ menunjukan bahwa ada pengaruh positif antara pengembangan karir dengan retensi karyawan sebesar 0,298.

Uji normalitas penelitian ini ditunjukan pada Tabel 10 .

Tabel 10.

Hasil Uji Normalitas

\begin{tabular}{ll}
\hline & Unstandardized Residual \\
\hline $\mathrm{N}$ & 68 \\
Kolmogorov-Smirnov Z & 1,027 \\
Asymp. Sig. (2-tailed) & 0,242 \\
\hline Sumber : Data diolah, 2018 &
\end{tabular}

Tabel 10 menguji apakah data yang digunakan normal atau tidak dapat dilakukan dengan menggunakan uji Kolmogorov-Smirnov jika nilai Asymp. Sig. (2tailed) lebih besar taraf signifikansi yang ditetapkan yaitu 5 persen $(0,05)$, maka 
data telah berdistribusi normal. Berdasarkan hasil analisis, diperoleh hasil sebesar 0,242> 0,05 yang artinya data berdistribusi normal.

Uji multikoleniaritas penelitian ini ditunjukan pada Tabel 11.

Tabel 11.

Hasil Uji Multikolinearitas

\begin{tabular}{lll}
\hline Model & Colinearity Statistic & \\
\cline { 2 - 3 } & Tolerance & VIF \\
\hline Kompensasi $\left(\mathrm{X}_{1}\right)$ & 0,470 & 2,127 \\
Kepuasan Kerja $\left(\mathrm{X}_{2}\right)$ & 0,389 & 2,568 \\
Pengembangan Karir $\left(\mathrm{X}_{3}\right)$ & 0,374 & 2,673 \\
\hline
\end{tabular}

Sumber : Data diolah, 2018

Tabel 11 mendeteksi ada atau tidaknya multikolinearitas dalam model regresi yaitu mempunyai angka Tolerance $>0,10$ atau mempunyai nilai VIF $<10$. Berdasarkan hasil analisis, dapat dilihat bahwa koefisien Tolerance semua variabel lebih besar dari 0,10 dan nilai VIF yang lebih kecil dari 10. Hasil ini mengindikasikan bahwa tidak terdapat gejala multikolinear dari model regresi yang dibuat sehingga pada model regresi ditemukan korelasi antar variabel bebas.

Uji Hesteroskedastisitas penelitian ini ditujukan pada Tabel 12.

Tabel 12. Hasil Uji Heteroskedastisitas

\begin{tabular}{|c|c|c|c|c|c|c|}
\hline & \multirow[t]{2}{*}{ Model } & \multicolumn{2}{|c|}{ Unstandardized Coefficients } & \multirow{2}{*}{$\begin{array}{c}\text { Standardized } \\
\text { Coefficients } \\
\text { Beta }\end{array}$} & \multirow[t]{2}{*}{$\mathrm{T}$} & \multirow[t]{2}{*}{ Sig. } \\
\hline & & B & Std. Error & & & \\
\hline \multirow{4}{*}{1} & (Constant) & 681 & 1.226 & & .555 & .581 \\
\hline & Kompensasi & -.016 & .046 & -.064 & -.351 & .727 \\
\hline & Kepuasan_Kerja & .042 & .088 & .096 & .482 & .632 \\
\hline & $\begin{array}{l}\text { Pengembangan } \\
\text { Karir }\end{array}$ & -.007 & .072 & -.020 & -.097 & .923 \\
\hline
\end{tabular}

Sumber: Data diolah, 2018

Tabel 12 menunjukkan bahwa nilai Sig. dari variabel kompensasi, kepuasan kerja, dan pengembangan karir masing-masing sebesar $0,727,0,632$, dan 0,923 
yang berarti tidak terdapat pengaruh antara variabel bebas terhadap absolute resiudal. Dengan demikian model yang dibuat tidak mengandung gejala heteroskedastisitas.

Hasil uji kelayakan model penelitian ini ditunjukkan pada Tabel 13.

Tabel 13.

Uji Anova

\begin{tabular}{llllll}
\hline Model & Sum of Squares & df & Mean Square & F & Sig. \\
\hline \multicolumn{1}{c}{ Regression } & 76.025 & 3 & 25.342 & 13.999 & $.000^{\mathrm{b}}$ \\
$1 \quad$ Residual & 115.857 & 64 & 1.810 & & \\
$\quad$ Total & 191.882 & 67 & & & \\
Sumber : Data diolah, 2018 & & & &
\end{tabular}

Tabel 13 menunjukkan nilai sig. $0,000<0,05$. Maka $\mathrm{H}_{0}$ ditolak pada taraf nyata 0,05 ( $\mathrm{H}_{1}$ diterima). Kesimpulannya, pada kelompok yang diuji memiliki perbedaan nyata (signifikansi), berarti bahwa variabel bebas yaitu kompensasi $\left(\mathrm{X}_{1}\right)$, kepuasan kerja $\left(\mathrm{X}_{2}\right)$, dan pengembangan karir $\left(\mathrm{X}_{3}\right)$ berpengaruh signifikan secara serempak atau bersama-sama terhadap variabel terikat yaitu retensi karyawan (Y).

Tabel 9 menunjukkan besarnya nilai Adjusted R square adalah sebesar 0,468 yang artinya sebesar 46,8 persen variasi retensi karyawan dipengaruhi oleh kompensasi, kepuasan kerja, dan pengembangan karir, sedangkan sisanya sebesar 53,2 persen dipengaruhi oleh faktor-faktor lain yang tidak dimasukkan ke dalam model penelitian.

Tabel 9 menunjukkan hasil uji t. Kriteria pengujian untuk menjelaskan interprestasi pengaruh antar masing-masing variabel sebagai berikut.

Jika Sig. $\mathrm{t}<0.05$ maka $\mathrm{H}_{0}$ ditolak dan $\mathrm{H}_{1}$ diterima.

Jika Sig. $\mathrm{t}>0.05$ maka $\mathrm{H}_{0}$ diterima dan $\mathrm{H}_{1}$ ditolak. 
(1) Pengaruh Kompensasi terhadap Retensi Karyawan.

Hasil analisis Tabel 9 diketahui bahwa variabel kompensasi terhadap retensi karyawan diperoleh nilai Sig. t 0,028 dengan nilai koefisien beta sebesar 0,193. Nilai Sig. t 0,028 < 0,05 mengindikasikan bahwa $\mathrm{H}_{0}$ ditolak dan $\mathrm{H}_{1}$ diterima. Hasil ini mempunyai arti kompensasi berpengaruh positif dan signifikan terhadap retensi karyawan.

(2) Pengaruh Kepuasan Kerja terhadap Retensi Karyawan.

Hasil analisis Tabel 9 diketahui bahwa variabel kepuasan kerja terhadap retensi karyawan diperoleh nilai Sig. t 0,032 dengan nilai koefisien beta sebesar 0,267. Nilai Sig. t 0,032<0,05 mengindikasikan bahwa $\mathrm{H}_{0}$ ditolak dan $\mathrm{H}_{1}$ diterima. Hasil ini mempunyai arti kepuasan kerja berpengaruh positif dan signifikan terhadap retensi karyawan.

(3) Pengaruh Pengembangan Karir terhadap Retensi Karyawan..

Hasil analisis Tabel 9 diketahui bahwa variabel pengembangan karir terhadap retensi karyawan diperoleh nilai Sig. t 0,016 dengan nilai koefisien beta sebesar 0,297. Nilai Sig. t 0,016 < 0,05 mengindikasikan bahwa $\mathrm{H}_{0}$ ditolak dan $\mathrm{H}_{1}$ diterima. Hasil ini mempunyai arti pengembangan karir berpengaruh positif dan signifikan terhadap retensi karyawan.

Pengaruh kompensasi terhadap retensi karyawan, hasil ini menunjukan bahwa kompensasi berpengaruh positif dan signifikan terhadap retensi karyawan. Kompensasi dapat mempengaruhi retensi karyawan ketika gaji yang dibayarkan tepat waktu, mendapatkan tunjangan, bonus, dan fasilitas bekerja. Artinya semakin baik kompensasi yang diberikan oleh Kutabex Hotel maka semakin kuat tingkat 
retensi karyawan tersebut. Hasil penelitian ini sesuai dengan hipotesis yang diajukan dan juga sesuai dengan hasil penelitian yang dilakukan oleh Kumar et al. (2012), Moncarz et al. (2009), Swambawa Putra 2016), Masqsood et al. (2015), dan Palwasha et al. (2016) yang menyatakan bahwa kompensasi berpengaruh positif signifikan terhadap retensi karyawan. Artinya jumlah kompensasi yang diberikan kepada karyawan dapat meningkatkan tingkat retensi karyawan tersebut.

Pengaruh kepuasan kerja terhadap retensi karyawan, hasil ini mempunyai arti kepuasan kerja berpengaruh positif dan signifikan terhadap retensi karyawan. Kepuasan kerja dapat mempengaruhi retensi ketika karyawan merasa puas akan pekerjaannya, mendapatkan kesempatan untuk dipromosikan dan hubungan yang baik dengan rekan kerjanya. Artinya semakin puas karyawan terhadap pekerjaan yang mereka lakukan di Kutabex Hotel maka semakin tinggi pula tingkat retensi karyawannya. Hasil penelitian ini sesuai dengan hipotesis yang diajukan dan juga sesuai dengan hasil penelitian yang dilakukan oleh Aydogdu dan Asikgil (2011), Das dan Baruah (2013), Witasari (2009), Astuti (2014), dan Motlou et al. (2016) yang menyatakan bahwa kepuasan kerja berpengaruh positif dan signifikan terhadap retensi karyawan. Artinya kepuasan kerja yang tinggi dapat meningkatkan tingkat retensi karyawan.

Pengaruh pengembangan karir terhadap retensi karyawan, hasil ini mempunyai arti pengembangan karir berpengaruh positif dan signifikan terhadap retensi karyawan. Pengembangan karir dapat mempengaruhi retensi ketika karyawan mendapatkan perlakuan adil dalam berkarir, atasan selalu mendukung karyawan untuk mengembangkan karirnya dan memiliki latar belakang pendidikan 
formal yang cukup untuk menunjang karirnya. Artinya peluang pengembangan karir yang diperoleh karyawan Kutabex tinggi dapat meningkatkan tingkat retensi karyawan. Hasil penelitian ini sesuai dengan hipotesis yang diajukan dan juga sesuai dengan hasil penelitian yang dilakukan oleh Kwenin (2013), Ongori dan Agolla (2009), Prince (2005), Mehta dan Kuberti (2014), dan Khan (2014) yang menyatakan bahwa pengembangan karir berpengaruh positif dan signifikan terhadap retensi karyawan. artinya pengembangan karir yang tinggi dapat meningkatkan tingkat retensi karyawan.

Hasil penelitian ini memiliki implikasi teori dan praktis. Secara teoritis penelitian ini menunjukan pengaruh positif dan signifikan dari kompensasi, kepuasan kerja dan pengembangan karir terhadap retensi karyawan. Implikasi praktis dari penelitian ini adalah Kutabex Hotel dapat lebih memperhatikan retensi karyawan di pengaruhi oleh kompensasi, kepuasan kerja dan pengembangan karir ini ditunjukkan oleh koefisien determinasi sebesar 46,8 persen, namun diperhatikan juga faktor lain yang mempengaruhi retensi karyawan seperti komitmen, kepemimpinan, motivasi dan lainnya.

Keterbatasan penelitian yang ditemui dalam penelitian ini adalah faktor yang mempengaruhi retensi karyawan pada penelitian ini hanya kompensasi, kepuasan kerja, dan pengembangan karir akan tetapi banyak faktor lain yang dapat digunakan oleh penelitian selanjutnya seperti rekrutmen, kinerja karyawan, komitmen organisasional, motivasi, lingkungan kerja dan lainnya. Ruang lingkup penelitian ini hanya pada satu objek penelitian saja alangkah baiknya bagi peneliti selanjutnya 
membandingkan tingkat retensi karyawan dari beberapa objek sehingga memberi gambaran lebih luas seberapa penting retensi karyawan bagi perusahaan.

\section{SIMPULAN DAN SARAN}

Simpulan dari hasil penelitian, berdasarkan hasil analisis dan pembahasan yang telah dipaparkan adalah sebagai berikut. Kompensasi memiliki pengaruh positif dan signifikan terhadap retensi karyawan di Kutabex Hotel. Hal ini menunjukan perlu diperhatikan mengenai gaji dan tunjangan yang diberikan kepada karyawan sesuai maka retensi karyawan akan meningkat. Kepuasan kerja memiliki pengaruh positif dan signifikan terhadap retensi karyawan di Kutabex Hotel. Hal ini menunjukan perlu diperhatikan mengenai dukungan dari atasan baik maka retensi karyawan akan meningkat. Pengembangan karir berpengaruh positif dan signifikan terhadap retensi karyawan. Hal ini menunjukan semakin tinggi peluang untuk menperoleh pengembangan karir maka retensi karyawan akan meningkat.

Saran yang dapat diberikan berdasarkan hasil analisis dan pembahasan adalah sebagai berikut. Pihak Kutabex hotel hendaknya dapat memberikan penghargaan atas pencapaian yang dilakukan oleh karyawan, karena ketika karyawan mendapatkan penghargaan atas kinerja yang dilakukannya, dengan begitu akan meningkatkan tingkat retensi karyawan sehingga pihak Kutabex hotel dapat mempertahankan karyawannya yang berkompeten di masing-masing bidang. Pihak Kutabex Hotel hendaknya dapat lebih memperhatikan seberapa menarik karyawan terhadap tanggung jawab pekerjaan yang dilakukannya, karena ketika karyawan merasa senang dengan pekerjaan sesuai tanggung jawabnya, dengan begitu karyawan akan termotivasi untuk meningkatkan kinerjanya dan karyawan akan 
tetap tinggal didalam perusahaan. Pihak Kutabex Hotel hendaknya dapat lebih memberi informasi mengenai promosi jabatan, karena ketika karyawan mendapatkan peluang untuk promosi jabatan, dengan begitu karyawan akan lebih merasa diperhatikan dan tingkat retensi karyawan didalam perusahaan semakin tinggi.

\section{REFERENSI}

A. Sihotang. (2007). Manajemen Sumber Daya Manusia. Jakarta: Pradnya Paramita.

Ahmed, Shaheen and Uddin, Md. Nokir. (2012). Job Satisfaction of Bankers and its Impact in Banking: A Case Study of Janata Bank. Journal ASA University Review. 6(2), pp :96-97.

Ahlrichs,J. L., Bloodworth, M. E., Chesters, G., and Nash, R. G. (2000). Pesticides in Soil and Water. Wisconsin USA: Soil Science Society of America, Inc. Publisher Madison. 8(2), pp: 192-197.

Anas, Khaidir. (2011). Pengaruh Kompensasi, Lingkungan Kerja Terhadap Kepuasan kerja Karyawan. E-Jurnal UNP. 2(1), hal: 1-11.

Ariana, I Wayan Tresna dan I Gede Riana. (2013). Pengaruh Kepemimpinan, Kompensasi dan Disiplin Kerja Terhadap Kinerja Karyawan Pada Hotel Cendana Resort \& Spa Ubud, Gianyar. E-Jurnal Manajemen Universitas Udayana. 2(1), hal: 122-123.

Arya Wibawa, I Gusti Agung Ketut. (2015). Pengaruh Kompensasi dan Lingkungan Kerja Terhadap Kinerja Karyawan. E-Jurnal Manajemen Universitas Udayana. 4(1), hal: 249-250.

Astuti, Diah Puji. (2014). Pengaruh Kompensasi Terhadap Retensi Karyawan Melalui Kepuasan Kerja dan Komitmen Afektif Pada Beberapa Rumah Sakit di DKI Jakarta. Jurnal Manajemen dan Pemasaran. 7(1), hal: 214-215.

Aydogdu, Sinem, and Asikgil, Baris. (2011). An literature review. Management Research and Practice. 3(4), pp: 77-86

Azem, S.M. 2-1-. Job Satisfaction and Organizational Commitment among Employees in the Sultanate of Oman. Journal of Psychology. 1, pp: 295-299.

Aziri, B. 2011. Job Satisfaction: A Literature Review. Management Research and Practice. 3(4), pp: 77-86. 
Das, Bidisha Lahkar dan Baruah, Mukulesh. 2013. Employee Retention : A Review of Literature. IOSR Journal of Business and Management (IORS-JBM). 14(2), pp: 13-14.

Fatima. 2011. Does Employee Retention Affect Organizational Competence. Industrial Engineering Letter. 1(1), pp: 24-39

Fitz-enz, J. (1990). Getting and keeping good employees. In personnel. 67(8), pp: $25-29$

Gillies, DA. 1989. Manajemen Keperawatan: Suatu Pendekatan Sistem. Edisi kedua. Terjemahan Illioni: WB Saunders Company.

Handaru. 2013. Pengaruh Lingkungan Kerja, Kompensasi Dan Komitmen Organisasi Terhadap Kepuasan Kerja Karyawan Di RS.X. Jurnal Riset Manajemen Sains Indonesia. 4(1), hal: 117-135.

Handoko, T. Hani. 2014. Manajemen Personalia dan Sumber Daya Manusia. Edisi Kedua. Yogyakarta: BPFE.

Haryani, Putu Yeni. 2013. Korelasi Antara Pengembangan Karir dengan Motivasi Kerja dan Keinginan Untuk Pensiun Dini. Jurnal Buletin Study Ekonomi. 2(6), hal: 116-120.

Hasibuan, Malayu S. P. 2011. Manajemen Sumber Daya Manusia. Edisi revisi. PT. Bumi Aksara: Jakarta.

Hong, Eric Ng Chee. 2012. An Effectiveness of Human Resource Management Practice on Employe Retention in Institute of Higher Learning: - A Regression Analysis. International Journal of Business Research Management (IJBRM). 3(2), pp: 63-64.

Iqbal, saba., Sadia, Ehsan., Ridwan, Muhammad dan Nooren, Mehwish. 2014. The Impact of Organizational Commitment, Job Satisfaction, Job Stress and Leadership Support on Turnover Intention in Educational Institutes. International Journal of Human Resource Studies. 4(2), pp: 181-195.

Jennifer A, Carsen. 2005. HR How To Employee Retention. Chicago : J.D. CCH Incorporated. 2(2), pp: 162-165.

Karthi. 2012. A Study On Employee Retention In Leading Multional Automobile Sector In India. Journal TQM. 2(9), pp: 1474-1482.

Kaseger, Regina Gledy. 2013. Pengembangan Karir Dan Self - Efficacy Terhadap Kinerja Karyawan Pada PT. Matahari Departement Store Manado Town Square. Jurnal EMBA. 4(1), pp: 342-350.

Khan, Rafique Ahmad. 2014. The Impact of Career Planing and Development On Job Satisfaction and Retention in Pakistan Banking Sector. Global Management Journal of Academic and Corporate Studies, 4(2), pp: 109-116. 
Kumar, Rames., Charles Ramendran dan Peter Jacob (2012). An Effectiveness of Human Resource Management Practices on Employee Retention in Institute of Higher learning: - A Regression Analysis. International Journal of Business Research and Management. 3(2), pp: 60-79.

Kwenin, Daisy Ofosuhene. 2013. Relationship Between Work Environment, Career Development Opportunities And Employee Retention In Vodafane Ghana Limited. Journal Of Human Resource Management, 1 (4), pp: 1-9.

Lubis, Rahman. 2015. Pengaruh Kompensasi, Lingkungan Kerja Dan Desain Tugas Terhadap Kepuasan Kerja Dan Dampaknya Terhadap Retensi Karyawan PMI. Jurnal Manajemen. 4(1), hal: 164-173.

Masqsood, Haider., Rasli, Amran., Akhtar, Chaudhry Shoaib., Yusoff, Rosman Bin Mohammesd., Malik, Mujahid Malik., Aamir, Alamxeb., Arif, Ahmed., Naveed, Shaheryar.,and Tariq, Fariha. 2015. The Impact of Human Resource Practices on Employee Retention in the Telecom Sector. International Journal of Economics and Financial Issues. 5(1), pp: 63-69.

Mehta, Mita dan Kurbetti, Aarti. 2014. Study On Employee Retention and Commitment. International Journal Of Advance Research in Computer Science and Management Studies, 2(2), pp: 144-145.

Mustika, I. K. 2012. Analisis Budaya Organisasi dan Kepuasan Kerja Melalui Komitmen Pengaruhnya Terhadap Intent to Leave Karyawan pada Industri Jasa Perhotelan di Kabupaten Badung dan Kota Denpasar. Jurnal Mitra Ekonomi dan Manajemen Bisnis. 3 (1), pp: 1-24.

Moncarz E, Zhao J, Kay C (2009). An Exploratory Study of US Lodging Properties Oganizational Practices On Employee Turnover and Retention. Int. J. Cont. Hosp. Manage. 21(4), pp: 437-458.

Motlou, Reyuben., Singh, Suveera., and Karodia, Anis Mahomed. 2016. An Evaluation of The Impact of Job Satisfaction On Employee Retention At Lonmin Rowland Shaft North West Province. Arabian Journal of Business an management Review. 5(10), pp: 15-49.

Oladopo, Victor. 2014. The Impact Of Talent Management On Retention. Journal of Business Studies Quarterly. 5(3), pp: 20-36.

Ongori, H. \& Agolla, J.E. 2009. Paradigm shift in managing career plateau in organisation: The best strategy to minimize employee intention to quit. African Journal of Business Management, 3(6), pp: 268-271.

Osteraker, Maria C (1999). Measuring motivation in a learning organization. Journal of Work Place Learning. 11(2), pp: 73-77.

Palwasha, Bibi., Ashfaq, Ahmad., and Abdul, HA Majid. 2016. The Moderating Role of Work Environment On the Relationship Between Compensation, Job 
Security, and Employee Retention. International Journal of Economic Perspective ; Famagusta. 10(4), pp: 726-738.

Prince, B.J. 2005. Career-Focused Employee Transfer Processes. Career Development International. 10(4), pp: 293-309.

Puangyoykeaw, Kevalin and Nishide, Yuko. 2015. Organizational Commitment and Turnover Intention in Low-Skilled Immigrant Worker in Thailand: An Empirical Assessment of Need Satisfaction, Job Satisfation and Overall Life Satisfaction Factors. International Journal of Businness and Management, 10(5), pp: 98-112.

Philip, Acheampong., Stacey, de Shield dan Ling Tsai. 2010. The Impact of Job Mobility, Hourly Compensation, \& Work Hours on Job Satisfaction. Institute For Research In Training \& Development Research Paper. 1(3), pp: 28-29.

Ragupathi, Dasam. 2013. The Employee Retention Practices of MNC'S in Hyderabad. Research Journal of Management Sciences. 2(4), pp: 21-24.

Rayadi. 2012. Faktor Sumber Daya Manusia Yang Meningkatkan Kinerja Karyawan dan Perusahaan Di Kalbar. Jurnal EKSOS. 8(2), pp: 114-119.

Rivai, Veithzal. 2011. Manajemen Sumber Daya Manusia Untuk Perusahaan. Jakarta: PT. Raja Grafindo Persada.

Rizwan, Muhammad. 2014. Preceding to employee satisfaction and turnover intention. International Journal Of Human Resource Studies. 4 (3) pp: 87106.

Sari, Eliana., Joni Sinulingga. 2011. Pengaruh Pengembangan Karir Dan Kompensasi Terhadap Motivasi Karyawan. Jurnal Ilmiah Penelitian Manajemen Manajerial. 2(1), pp: 431-440.

Simamora, Henry. 2004. Manajemen Sumber Daya Manusia. Edisi Ketiga. Yogyakarta: STIE YKPN.

Sudiro, Ahmad. 2011. Perencanaan Sumber Daya Manusia. Malang: Universitas Brawijaya Press.

Sugiyono. 2016. Metode Penelitian Administratif Dilengkapi Dengan Metode $R$ \& $D$. Bandung: Alfabeta.

Sumarni, Murti. 2011. Pengaruh Eploye Retention Terhadap Turnover Intention dan Kinerja Karyawan. Jurnal Akmenika. 8 (2), pp: 20-47.

Susilo, Andri. 2013. Pengaruh Retensi Karyawan dan Kepuasan Pelanggan Terhadap Kinerja. Jurnal Studia Akuntansi dan Bisnis. 1(3), pp: 247-262.

Suwanto, dan Priansa, D.J. 2011. Manajemen SDM dalam Organisasi Publik dan Bisnis. Bandung: Alfabeta. 
E-Jurnal Manajemen Unud, Vol. 7, No. 11, 2018: 5814 - 5845

Swambawa Putra, Ida Bagus. 2016. Pengaruh Kompensasi, Lingkungan Kerja, dan Percieved Organizational Support (POS) Terhadap Retensi Kerja. E-Jurnal Manajemen Unud. 5(2), pp: 829-830.

Swaminathan, Samanvitha. 2013. Job Statisfaction as A Predictor of Organizational Citizenship Behavior : An Empirical Study. Global Journal of Business Research. 7(1), pp:71-76.

Vicky, Antonius. 2012. Analisis Pengaruh Kompensasi, Manajemen Konflik pada Retensi Karyawan dan Dampaknya Terhadap Kinerja Karyawan Di Pasifik Perusahaan Niaga Jaya. Skripsi Binus University Jakarta, Indonesia.

Witasari, L. 2009. Analisis Pengaruh Kepuasan Kerja dan Komitmen Organisasional Terhadap Turnover Intention Studi Empiris pada Novotel Semarang. Tesis. Universitas Diponegoro. 